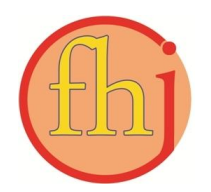

Faletehan Health Journal, 6 (2) (2019) 64-68

www. journal.Ippm-stikesfa.ac.id/ojs/index.php/FHJ

ISSN 2088-673X | e-ISSN 2597-8667

\title{
Pengaruh Pengetahuan Tentang Dampak Gadget Bagi Kesehatan Terhadap Perilaku Penggunaan Gadget Pada Siswa SDN Kebun Bunga 6 Banjarmasin
}

\author{
Septi Anggraen $\mathbf{i}^{*}$ \\ ${ }^{1}$ Fakultas Kesehatan M asyarakat, Universitas Islam Kalimantan, Indonesia \\ *Corresponding Author: septi_0323@yahoo.co.id
}

\begin{abstract}
Abstrak
Kemajuan zaman di bidang ilmu teknologi semakin berkembang. Teknologi yang sangat popular di era globalisasi ini adalah gadget. Penggunaan gadget pada anak semakin meningkat. Akademi Dokter Anak Amerika dan Perhimpunan Dokter Anak Kanada menegaskan perlu adanya batasan dalam penggunaan teknologi pada anak, anak umur 6-18 tahun dibatasi menggunakan hanya 2 jam perhari. Anak-anak dan remaja yang menggunakan teknologi melebihi batas waktu yang dianjurkan memiliki risiko kesehatan. Kurangnya pemahaman tentang dampak penggunaan gadget menjadikan anak berperilaku menggunakannya secara berlebihan. Tujuan penelitian ini adalah untuk mengetahui pengaruh pengetahuan tentang dampak gadget pada kesehatan terhadap perilaku penggunaan gadget pada siswa SDN Kebun Bunga 6 Banjarmasin. Penelitian ini merupakan penelitian survey analitik dengan pendekatan cross sectional. Populasi dalam penelitian ini adalah seluruh siswa kelas VI SDN Kebun Bunga 6 Banjarmasin. Sampel pada penelitian ini adalah total dari populasi yaitu sebanyak 50 siswa. Hasil analisis Regresi Linear sederhana menunjukkan adanya pengaruh pengetahuan tentang dampak gadget pada kesehatan terhadap perilaku penggunaan gadget pada siswa ( $p$ value $=0,002$ ) dengan besar pengaruh $18,9 \%$. Dalam hal ini perlu adanya peningkatan pengetahuan siswa tentang dampak gadget pada kesehatan, karena semakin tinggi pengetahuan akan dikuti dengan penurunan perilaku penggunaan gadget.
\end{abstract}

Kata Kunci: Dampak kesehatan, Gadget, Pengetahuan, Perilaku

\begin{abstract}
The progress of the age in the field of technology is growing. The technology that is very popular in this era of globalization is a gadget. The use of gadgets in children is increasing. The Academy of American Pediatricians and the Canadian Pediatricians Association stresses the need for limitations in the use of technology in children, children aged 6-18 years are limited to using only 2 hours per day. Children and adolescents who use technology exceed the recommended time limit have health risks. Lack of understanding about the impact of using gadgets makes children behave using it excessively. The purpose of this study was to determine the effect of knowledge about the impact of gadgets on health on the behavior of gadget use in students of Kebun Bunga 6 Banjarmasin Elementary School. This study is an analytical survey research with a cross sectional approach. The population in this study were all students of class VI. The sample in this study is the total of the population as many as 50 students. The results of a simple Linear Regression analysis show the influence of knowledge about the impact of gadgets on health on the behavior of gadget use in students ( $p$ value $=0.002$ ) with a large influence of $18.9 \%$. In this case it is necessary to increase students' knowledge about the impact of gadgets on health, because the higher the knowledge will be followed by a decrease in the behavior of using gadgets.
\end{abstract}

Keywords: Gadget, Knowledge, Health impact, Behavior 
Faletehan Health Journal, 6 (2) (2019) 64-68

\section{Pendahuluan}

Kemajuan zaman di bidang ilmu teknologi semakin berkembang. Teknologi yang sangat popular di era globalisasi ini adalah gadget. Gadget dahulu hanya digunakan oleh kalangan menengah ke atas, namun pemakaiannya sekarang ini sudah digunakan berbagai kalangan, mulai dari anak usia dini hingga orang dewasa.

Gadget merupakan suatu istilah yang digunakan dalam menyebut beberapa macam jenis alat teknologi yang sifatnya semakin berkembang pesat dan memiliki fungsi khusus. Contoh dari gadget yaitu smartphone, $i$ phone, komputer, laptop dan tab (Manumpil, 2015).

Penggunaan gadget pada anak semakin meningkat. Berdasarkan penelitian yang dilakukan oleh Rideout diketahui bahwa terjadi peningkatan penggunaan media dan gadget pada anak yaitu 38\% pada tahun 2011 dan meningkat menjadi $72 \%$ pada tahun 2013. Salah satu faktor yang mendasari meningkatnya persentase anak yang menggunakan gadget yaitu karena semakin berkembangnya teknologi. Seiring berkembangnya teknologi, maka gadget tampil dengan sistem touch screen yang membuat siapapun lebih mudah untuk menggunakannya, terutama anak kecil yang belum bisa membaca sekalipun, seperti penggunaan smartphone (Iswidharmanjaya, 2014).

Pada umumnya anak-anak menggunakan gadget untuk bermain game, menonton animasi, bermain internet dan sebagai media pembelajaran.

Akademi Dokter Anak Amerika dan Perhimpunan Dokter Anak Kanada menegaskan, anak umur 0-2 tahun tidak boleh terpapar oleh teknologi sama sekali. Anak umur 3-5 tahun dibatasi menggunakan teknologi hanya satu jam perhari dan anak umur 6-18 tahun dibatasi 2 jam saja perhari. Anak-anak dan remaja yang menggunakan teknologi melebihi batas waktu yang dianjurkan memiliki risiko kesehatan serius. (Rowan, 2013).

Penggunaan gadget yang berlebihan bisa membawa dampak yang cukup besar bagi tumbuh kembang anak. Salah satunya perihal berkurangnya aktivitas fisik yang seharusnya dilakukan sang anak. Selain itu, dampak negatif lain dari penggunaan gadget adalah bila durasinya terlalu lama digunakan bisa berakibat pada mata dan otak. Beberapa penelitian menunjukan bahwa dampak penggunaan gadget antara lain adalah terganggunya pertumbuhan otak anak, obesitas, kurang tidur, kelainan mental, sifat agresif serta radiasi emisi. Untuk itu perlu adanya batasan dalam menggunakan gadget pada anak.

Perilaku penggunaan gadget dipengaruhi oleh berbagai faktor, salah satunya adalah pengetahuan. Kurangnya pemahaman tentang dampak penggunaan gadget menjadikan anakanak berperilaku menggunakan gadget secara berlebihan.

Hasil studi pendahuluan pada 5 siswa di SDN Kebun Bunga 6 Banjarmasin diperoleh hasil bahwa ke lima siswa tersebut memiliki gadget seperti tablet dan smartphone. Tiga dari 5 siswa menyatakan bahwa lama penggunaan gadget dalam sehari yaitu lebih dari 2 jam dan penggunaanya lebih banyak di peruntukan untuk bermain game serta beberapa dari lima siswa tersebut menyatakan bahwa setelah menggunakan gadget dalam durasi yang cukup lama, mereka mengeluhkan kelelahan pada mata dan alat gerak motorik.

Berdasarkan latar belakang masalah di atas maka tujuan penelitian ini adalah untuk mengetahui pengaruh pengetahuan tentang dampak gadget pada kesehatan terhadap perilaku penggunaan gadget pada siswa SDN Kebun Bunga 6 Banjarmasin.

\section{Metode Penelitian}

Penelitian ini merupakan penelitian survey analitik dengan pendekatan cross sectional. Populasi dalam penelitian ini adalah seluruh siswa kelas VI SDN Kebun 6 Banjarmasin. Sampel pada penelitian ini adalah total dari populasi yaitu sebanyak 50 siswa. Instrumen yang digunakan dalam penelitian ini adalah menggunakan lembar kuesioner yang telah dilakukan uji validitas dan uji reliabilitas. Analisis data menggunakan uji Regresi Linear sederhana dengan $\alpha=0,05$.

\section{Hasil dan Pembahasan}

Pada penelitian ini karakteristik responden berdasarkan jenis kelamin. Sebagian besar responden pada penelitian ini berjenis kelamin laki-laki yaitu sebanyak 28 responden (56\%). Distribusi Karakteristik responden berdasarkan jenis kelamin dapat dilihat pada Gambar 1. 
Berdasarkan gambar 2 dapat diketahui bahwa sebesar $32 \%$ yaitu 16 responden berpengetahuan baik, 12 responden (24\%) berpengetahuan yang cukup dan sebanyak 22 responden (44\%) memiliki pengetahuan kurang tentang dampak penggunaan gadget bagi kesehatan. Sebagian responden banyak yang tidak mengetahui akibat penggunaan gadget dalam waktu yang lama bisa berdampak pada kesehatan terutama pada otak, mata, dan interaksi sosial.

Gambar 3 menunjukkan bahwa sebagian besar responden yaitu sebanyak 27 responden (54\%) memiliki perilaku penggunaan gadget yang berisiko dan sebanyak 23 responden $(46 \%)$ berperilaku tidak berisiko.

Gadget dapat memberikan dampak positif maupun negatif bagi penggunanya, baik pengguna di usia anak-anak ataupun dewasa. Salah satu faktor yang berperan dalam pemberian dampak gadget yaitu durasi penggunaannya. Menurut penelitian sebelumnya, yang dilakukan oleh Salsabila (2016) mengatakan bahwa lama atau durasi penggunaan gadget oleh anak-anak dapat memberikan pengaruh terhadap perkembangannya. Hal tersebut di dukung oleh hasil penelitian Novitasari dan Khotimah (2016) bahwa pengenalan gadget terlalu dini pada anak dapat mempengaruhi interaksi sosial anak.

Menurut penelitian yang dilakukan oleh Rideout didapatkan hasil bahwa terdapat anak usia 2 sampai 4 tahun telah menghabiskan waktunya di depan layar selama 1 jam 58 menit perharinya dan anak usia 5 hingga 8 tahun menghabiskan waktu di depan layar selama 2 jam 21 menit setiap harinya. Hal ini bertentangan dengan pendapat Starburger yang menyatakan bahwa anak hanya boleh berada di depan layar $<1$ jam setiap harinya.

Hasil penelitian menunjukkan bahwa sebagian besar siswa kelas VI SDN Kebun 6 Banjarmasin (54\%) memiliki kebiasaan menggunakan gadget lebih dari 2 jam dalam setiap harinya. Berdasarkan Hasil analisis data menunjukkan bahwa pada responden laki-laki lebih banyak yang berperilaku berisiko $(60,7 \%)$ dibandingkan dengan perilaku tidak berisiko $(39,3 \%)$ dalam penggunaan gadget. sedangkan pada responden perempuan, lebih banyak yang berperilaku tidak berisiko $(54,6 \%)$ dibandingkan dengan perilaku berisiko $(45,4 \%)$ dalam penggunaan gadget. Jadi, perilaku penggunaan gadget yang berisiko lebih banyak terjadi pada responden laki-laki dibandingkan dengan responden perempuan.

Penggunaan gadget yang tidak bijak yaitu penggunaan secara berlebihan bisa berdampak buruk bagi kesehatan psikis dan jasmani. Dengan penggunaan gadget secara berlebihan seseorang dapat mengalami berbagai macam gangguan seperti gangguan pendengaran, penglihatan, tingkat agresif pada anak,tidak peka terhadap lingkungan dan dapat membuat seseorang menjadi susah tidur. Gadget juga dapat memicu penyakit serius seperti kanker karena radiasi yang dikeluarkan.

Gambar 1. Karakteristik Responden Berdasar Jenis Kelamin

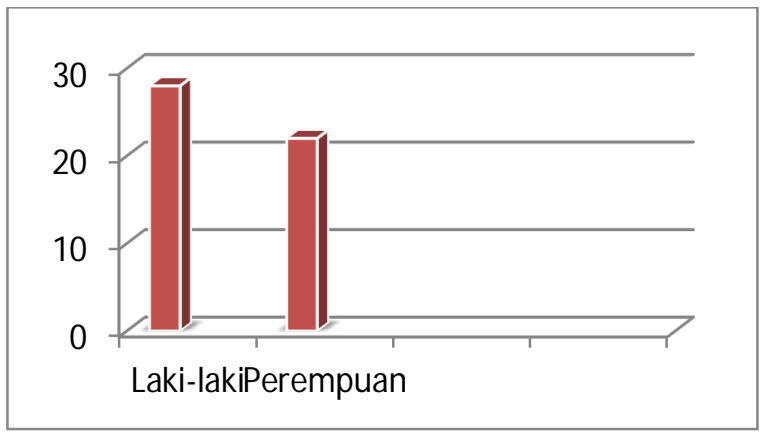

Gambar 2. Pengetahuan Tentang Dampak Penggunaan Gadget Pada Kesehatan

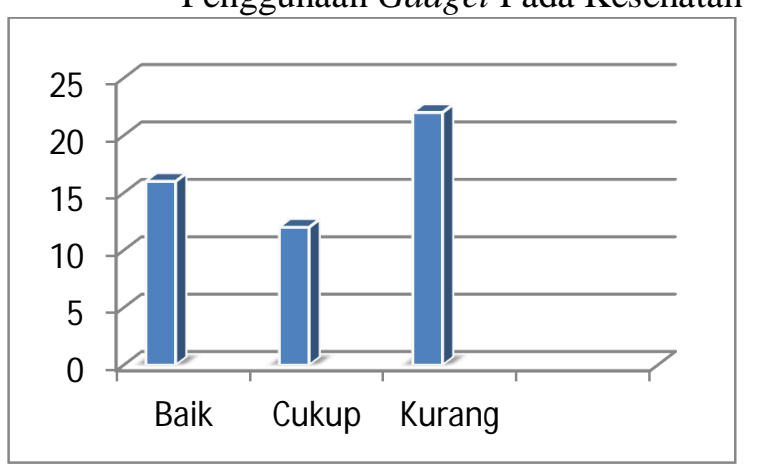

Gambar 3. Perilaku Penggunaan Gadget Pada Siswa

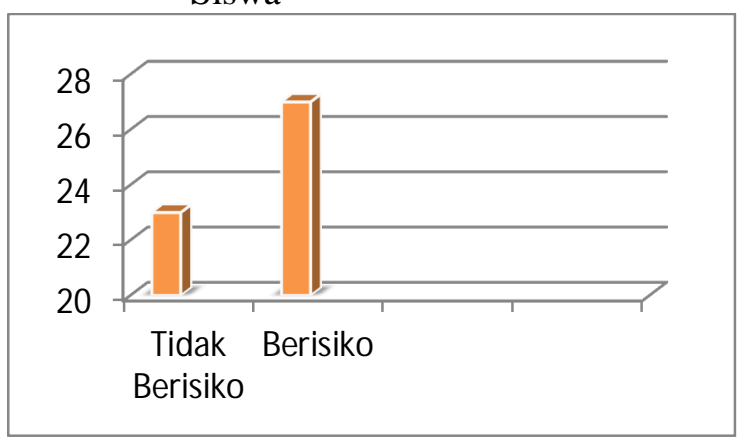


Faletehan Health Journal, 6 (2) (2019) 64-68

www. journal.Ippm-stikesfa.ac.id/ojs/index.php/FHJ

ISSN 2088-673X | 2597-8667

\section{Analisis Bivariat \\ Pengaruh Pengetahuan Tentang Dampak Gadget Bagi Kesehatan Terhadap Perilaku Penggunaan Gadget Pada Siswa}

Berdasarkan hasil uji regresi didapatkan bahwa nilai signifikansi penelitian ini adalah sebesar 0.002 yang berarti bahwa model regresi adalah linier. Dengan demikian model persamaan regresi berdasarkan data penelitian adalah signifikan dan memenuhi kriteria linieritas. Dengan nilai F sebesar 11,164 maka dapat dikatakan bahwa terdapat pengaruh pengetahuan terhadap perilaku penggunaan gadget pada siswa. Adapun model persamaan regresinya adalah sebagai berikut: $\mathrm{Y}=7,882-0.288 \mathrm{X}$

Berdasarkan tabel 1, diketahui nilai koefisien determinasi sebesar 0,189 yang menunjukan bahwa variabel pengetahuan memiliki pengaruh kontribusi sebesar 18,9\% terhadap variabel perilaku. Sedangkan sisanya, sebesar 81,1\% dipengaruhi oleh faktor-faktor lain diluar dimensi-dimensi pada variabel pengetahuan.

Hasil analisis data menunjukan bahwa pengetahuan siswa tentang dampak penggunaan gadget bagi kesehatan terhadap perilaku penggunaan gadget di SDN Kebun 6 Banjarmasin memiliki hubungan yang negatif dengan perilaku penggunaan gadget pada siswa yang berarti bahwa semakin tinggi pengetahuan siswa tentang dampak gadget pada kesehatan akan dikuti dengan penurunan perilaku penggunaan gadget dan sebaliknya jika pengetahuan tentang dampak gadget pada kesehatan rendah maka akan dikuti dengan peningkatan perilaku penggunaan gadget.

Hasil penelitian ini sejalan dengan hasil penelitian Tamsuri Anas (2011) yang menyatakan bahwa Ada hubungan antara pengetahuan remaja tentang dampak penggunaan handphone dengan perilaku penggunaan handphone dengan hasil korelasi 0,269 dengan uji signifikansi $(p)=0,000$

Pengetahuan atau kognitif merupakan domain yang sangat penting dalam membentuk tindakan seseorang. Pengetahuan sangat penting di dalam seseorang mengambil keputusan karena tindakan yang didasarkan atas pengetahuan memberikan konsekuensi yang lebih baik bagi pengambil keputusan. Pengetahuan merupakan faktor predisposisi yang menentukan perilaku seseorang (Notoatmodjo, 2012)
Tabel 1. Model Summary

\begin{tabular}{|c|c|c|c|c|}
\hline $\begin{array}{l}\text { Mod } \\
\text { el }\end{array}$ & $\mathrm{R}$ & $\begin{array}{c}\mathrm{R} \\
\text { Square }\end{array}$ & $\begin{array}{c}\text { Adjusted R } \\
\text { Square }\end{array}$ & $\begin{array}{l}\text { Std. Error of } \\
\text { the Estimate }\end{array}$ \\
\hline 1 &, $434^{\mathrm{a}}$ & , 189 &, 172 & 908 \\
\hline
\end{tabular}

a. Predictors: (Constant), pengetahuan

Tabel 2. ANOVA ${ }^{\mathrm{a}}$

\begin{tabular}{lrrrrr}
\hline Model & $\begin{array}{c}\text { Sum of } \\
\text { Squares }\end{array}$ & \multicolumn{4}{c}{$\begin{array}{c}\text { Sf } \\
\text { Square }\end{array}$} \\
\hline Regressi & 9,212 & 1 & 9,212 & 11,164 &, $002^{\mathrm{b}}$ \\
on & & & & & \\
Residual & 39,608 & 48 &, 825 & & \\
Total & 48,820 & 49 & & & \\
\hline
\end{tabular}

a. Dependent Variable: perilaku

b. Predictors: (Constant), pengetahuan

Tabel 3. Coefficients ${ }^{\mathrm{a}}$

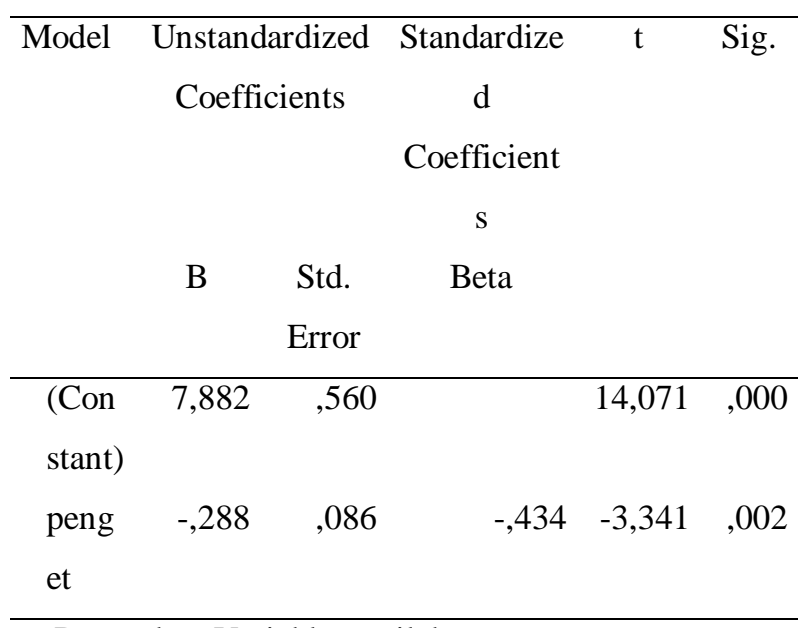

a. Dependent Variable: perilaku

\section{Simpulan}

Berdasarkan hasil penelitian ini dapat disimpulkan bahwa ada pengaruh pengetahuan tentang dampak gadget bagi kesehatan terhadap perilaku penggunaan gadget pada siswa SDN Kebun Bunga 6 Banjarmasin.

\section{Referensi}

Iswidharmanjaya D \& Agency B. (2014). Panduan Bagi Orang Tua Untuk Memahami Faktor-Faktor Anak Kecanduan Gadget. Bisakimia. 
Manumpil B, Ismanto Y OF. (2015). Hubungan Penggunaan Gadget Dengan Tingkat Prestasi Siswa Di SMA Negeri 9 Manado. Ejournal keperawatan Vol 3.

Notoatmodjo S. (2012). Promosi Kesehatan dan Perilaku Kesehatan. Jakarta: PT Rineka Cipta

Novitasari W \& Khotimah N. (2016). Dampak Penggunaan Gadget Terhadap Interaksi Sosial Anak Usia 5-6 Tahun. J PAUD Teratai Vol 5.

Rideout V. (2013). Zero to eight: electronic media inthe lives of infants, toddlers and preschoolers. Common Sense Media Research Study.

Rowan C. (2013). The impact of technology on the developing child [internet]. US: The
Huffington.

http://www.huffingtonpost.com/crisrowan/technologychildren-negative impact_b_3343245.html. Diakses pada 30 Maret 2018.

Salsabila S.(2016). Pengaruh Lama Penggunaan Gadget Terhadap Perkembangan Anak di TK Al-Azhar Banda Aceh. Banda Aceh.

Starburger VC. (2011) . Children, adolescents, obesity and the media. Pediatrics.

Tamsuri, A \& Bayu P. (2011). Hubungan Pengetahuan Tentang Dampak Penggunaan Handphone Pada Kesehatan Dengan Perilaku Penggunaan Handphone Pada Remaja. Jurnal AKP No.4. 